\title{
Virtual Attendance: Analysis of an Audiovisual over IP System for Distance Learning in the Spanish Open University (UNED)
}

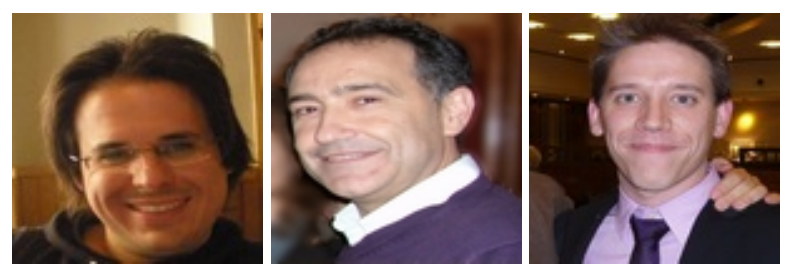

Esteban Vázquez-Cano ${ }^{1}$, Javier Fombona², and Alberto Fernández²

${ }^{1}$ Spanish National University of Distance Education (UNED), Spain, ${ }^{2}$ University of Oviedo, Spain

\section{Abstract}

This article analyzes a system of virtual attendance, called "AVIP" (AudioVisual over Internet Protocol), at the Spanish Open University (UNED) in Spain. UNED, the largest open university in Europe, is the pioneer in distance education in Spain. It currently has more than 300,000 students, 1,300 teachers, and 6,000 tutors all over the world, besides Spain. This university is redefining, on the lines of other universities, many of its academic processes to meet the new requirements of the European Higher Education Area (EHEA). Since its inception, more than 30 years ago, the methodology chosen by UNED has been blended learning. Today, this university combines face-to-face tutorial sessions with new methodological proposals, mediated by ICT. Through a quantitative methodology, the perception of students and tutors of the new model of virtual tutoring, called AVIP Classrooms, was analyzed. The results show that the new model greatly improves the orientation and teaching methodology of tutors. However, it requires training and new approaches to provide a more collaborative and participatory environment for students.

Keywords: Virtual attendance; distance education; ICT; video tutoring; blended learning 


\section{Introduction}

The Spanish Open University (UNED) is the largest European open university and one of the largest in the world with more than 300,000 students, 1,300 teachers, and 6,000 tutors. Its distance learning system combines ICT with personalized attention for students through a central site in Madrid and a network of over 60 associated centers distributed throughout Spain and different continents (South and North America, Europe, and Africa). Open universities' students need continuous support during their knowledge construction process, and for this purpose, UNED delivers optional face-toface workshops every seven days by tutors who facilitate and guide the students in a self-learning process of incorporating new knowledge in their daily personal, academic, and professional lives. This tuition, adapted to the needs of the European Higher Education Area (EHEA), was organized using blended learning methodology, an online learning platform called "aLF" and a variety of digital resources favoring networking through Regional Campus. In this context, technologically eminent UNED recently developed a program called ATECA (Educational Technology Architecture for the Associated Centers) with the help of European funds "FEDER". The objective of this plan has been to strengthen "virtual attendance", which involves creating classrooms with videoconferencing over synchronous IP ("AVIP-Classrooms") enabling the associated centers to deliver tutoring and mentoring services to geographic areas that were previously beyond reach. The tool combines high-end video-conferencing with low-end web-conferencing and smart board-based learning. It also enables resource manipulation, besides developing digital content repositories in a way that allows the use of virtual attendance within the European Higher Education Area in a blended learning environment. The new AVIP classroom system permits almost the same types of interaction in distance learning that are possible in traditional face-to-face learning scenarios (Dennen, Darabi, \& Smith, 2007; Chou \& Min, 2009; Rehm, 2009; Hurtado \& Guerrero, 2011; Chickerur \& Kumar, 2011).

For supporting tutoring and creating a common ICT mediated learning environment, these services require efficient interactivity through video, audio, and educational content of the highest possible quality; in this sense, it is important to use the visual language effectively (Fombona, 2008). This interactivity is achieved through proprietary communication software developed at UNED, called "AVIP Classrooms Level $1+$ Audiovisual IP". Aided by this videoconference system and with tutor support, UNED generates shared workspaces to minimize the training requirements and to extend the tutoring services nationwide at reasonable cost. AVIP Classrooms are organized at two levels:

- Level 1: AVIP classrooms, equipped with videoconferencing systems and interactive whiteboard using Multipoint Control Units (MCU) that enable simultaneous connectivity with several centers and classrooms. 
- Level 2 (Capture sessions [seminars, tutorials ...]): Contents are transmitted from classrooms and online conference rooms for storage and delayed live broadcast.

The AVIP (AudioVisual over IP) tool provides "virtual attendance"; that is, students and tutors can access classroom activities of any center from any center or classroom. This facility can be developed "live" (online) for broadcasting seminars or classes at scheduled times, and for "on replay" (off line), through access to information on demand (VOD), along with related documentation that may have been stored on the same server.

This technology facilitates robust interpretation of blended learning which promotes social presence with the benefits of online teaching and learning (Kumar \& Benbasat, 2002; Shin, 2002). It further enables exploration of learning designs which utilize social processes in promoting understanding of the social motivation of users, in improving social affordances of telecommunications systems, and in enhancing research of social cognition, interpersonal communication, and theories of mind (Biocca et al., 2003; Lee, \& McLoughlin, 2010; Vázquez, 2011, Vázquez \& Sevillano, 2012; Vázquez \& López, 2012).

This paper analyzes, through a quantitative methodology, the perception of students and tutors about the functionality, difficulties, and challenges of AVIP classrooms and undertakes a preliminary assessment of their efficacy in planning improvement of virtual processes in distance university studies.

\section{Virtual Attendance: More than Blended Learning}

Blended learning is favored in teaching and learning environments where there is an effective integration of different modes of delivery, models of teaching, and styles of learning as a result of adopting a strategic and systematic approach to using technology in combination with the best features of face-to-face interaction (Tu \& McIsaac, 2002; Krause, 2007). According to Garrison and Kanuka (2004), the simplest model of blended learning "is the thoughtful integration of classroom face-to-face learning experiences with online learning experiences", which aims at taking advantage of a synchronous face-to-face situation and the asynchronous, text-based Internet. Typically, this means traditional face-to-face teaching or lecturing with additional online materials and learning assignments, using different learning management systems, such as Moodle or other digital platforms. Thus, from the blended learning point of view, social software provides interesting opportunities to support collaborative learning (Ferdig, 2007; Brindley, Walti, \& Blaschke, 2009; Conole, 2010). However, researchers have approached this concept from different points of view. The three most commonly mentioned definitions documented are as follows: 
1. combining instructional modalities (or delivery media) (Singh \& Reed, 2001; Orey, 2002);

2. combining instructional methods (Driscoll, 2002; Rossett, 2002);

3. combining online and face-to-face instruction (Reay, 2001; Young, 2002; Sands, 2002; Rooney, 2003; Ward \& LaBranche, 2003).

Other authors, like Köse (2010), consider blended learning as advantageous for using different tools of social software in producing material, in demonstrating knowledge, and in communicating. In fact, distance learning in Spanish Open University tries to reach higher standards of interactivity than those of blended learning. This development is called "virtual attendance" (Read, Verdejo, \& Barros, 2003). It is defined as the audience feeling as if they are in a computer generated environment that is like reality (Gaspar et al., 2008; Arzuaga \& Kaeli, 2010). Witmer and Singer (1998) define this kind of presence as the subjective experience of being in a place or environment, even when one is physically situated elsewhere. It is relevant to compare social presence with virtual presence and investigate hybrid collaborative environments where several modes of interaction are provided, because both of them-social and virtual presence- can improve performance (Harms, et al., 2006; LaPointe \& Reisetter, 2008; Caspi \& Blau, 2008).

The new system of audiovisual attendance, in comparison to the usual blended learning systems, improves both task performance and perceived affordances. Virtual attendance generates social presence in one aspect: "involves the degree to which media are capable of making users perceive other users' sociability, warmth, sensitivity, personality, or closeness in a mediated communication situation". Others interpret the concept in different ways: "the feeling that others are involved in the communication process" (Whiteman, 2002, p. 6); "the degree to which a person feels 'socially present"' (Heeter, 2003, p. 340); "the degree of person-to-person awareness" (Leh, 2001, p. 10; Tu, 2002, p. 1662); "the sense of being present in a social encounter with another person" (McLellan, 1999, p. 40); and "the degree to which participants are able to project themselves affectively within the medium" (Garrison, 1997, p. 6).

However, Gunawardena and Zittle (1997, p. 9) put it most simply when they say that social presence in virtual environments is "the degree to which a person is perceived as a real person in mediated communication". A high degree of virtual presence means that participants will have a "sense of being in and belonging in a course and the ability to interact with other students and an instructor, although physical contact is not available" (Shin, 2002). The learners feel cognitively present to tasks and experience mentally the state of "being there" in the distance learning system (Young, Birtolo, \& McElman, 2009). "Physical presence implies being present in (or present to) the virtual or real environment: being there" (Heeter, 2003, p. 341). A sense of presence can be 
achieved if the system is interactive and highly responsive in a many-to-many context communication (Schroeder, Minocha, \& Schneider, 2010; Lee \& McLoughlin, 2010).

As Whiteman (2002, p. 8) states, "people feel more comfortable around us when they believe we share a kinship and common values". When the environment lacks social presence, the participants see it as impersonal and, as a result, the amount of information shared with others decreases (Leh, 2001; Tallent-Runnels et al., 2006). The overall goal of creating social presence-online or face-to-face-in any learning environment is to create a level of comfort in which people feel at ease around the tutor and other participants. Failing this, the learning environment cannot be fulfilling or successful for instructors and learners.

\section{VideoTutoring Model over IP: AVIP Classrooms 1 and 1+}

The AVIP classroom structure is organized in one of the two modes: Classrooms AVIP (Level 1 and Level $1+$ ) or online tutoring (Level $2+$ ). These classrooms allow synchronous teaching and tutoring at different locations.

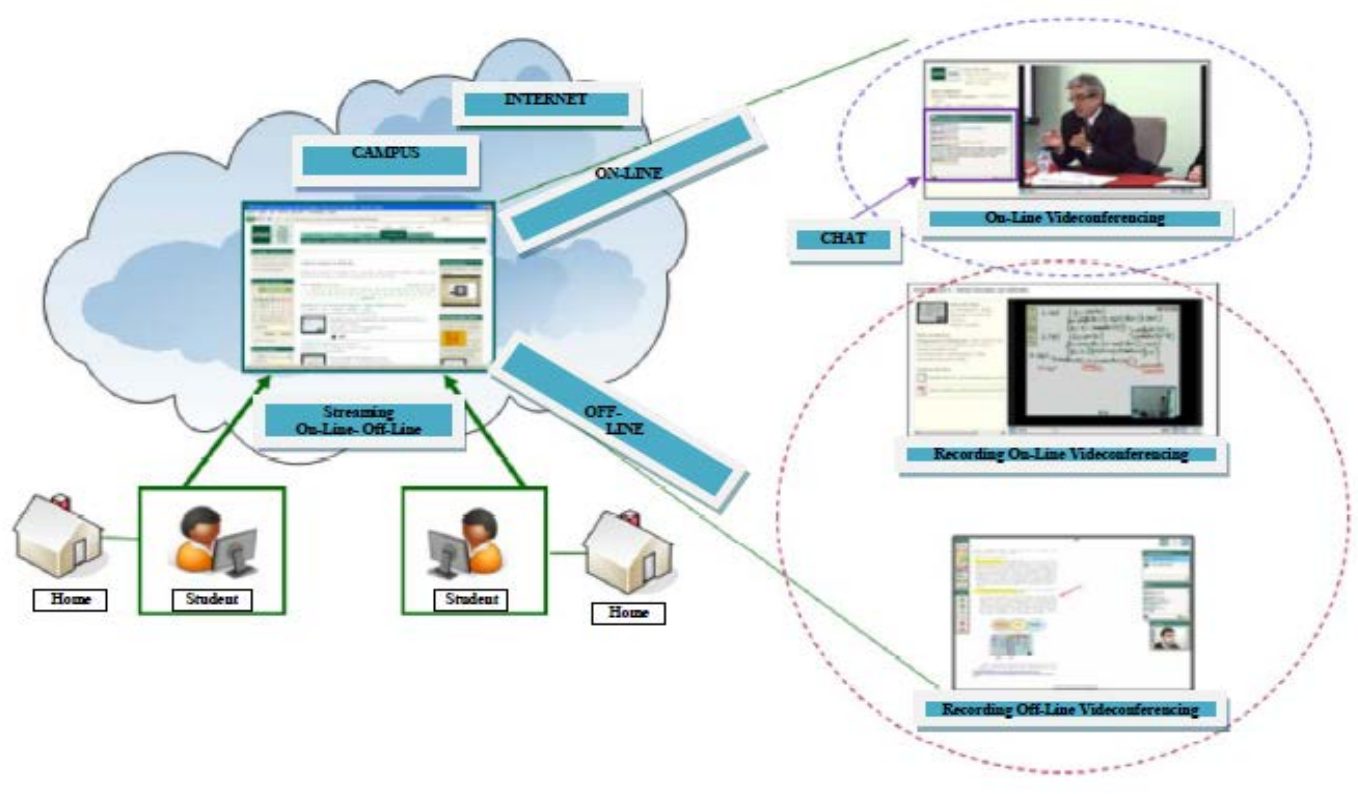

Figure 1. UNED-AVIP.

\section{AVIP Classrooms (Level 1+)}

Level 1 is provided with high-end video conferencing over an interactive whiteboard (PDI) in classrooms of associated centers. The goal is to conduct tutoring classes simultaneously in several physically separate classrooms. The contents offered can be 
"live", which necessarily requires the student and tutor to be in an AVIP classroom or in streaming "off-line". Some items of the videoconferencing equipment used are Polycom or Tandberg. Videoconferencing technology is built up with ISDN or Internet (with sufficient bandwidth guaranteed). Interactive whiteboards also require an internet connection to Network-UNED for interconnection with others. The most used tool in interactive whiteboard is the "online whiteboard" which allows connectivity among whiteboards of different manufacturers. This type of synchronous tool 2.0 is characterized by the following features:

- It is possible to create whiteboard rooms.

- Each room supports a maximum of eight participants.

- Access to each room requires a password to prevent entry of strangers into the system.

- All students can interact with the board, and if someone creates a new page, everyone else can view and save the page as PDF with annotations for future reference.

- "Document viewer" is available where one can upload documents for presentation.

- Tutors' presentations can be downloaded to different AVIP classrooms.

The main objective of this new technology architecture is to offer the user a teachinglearning environment that ensures "virtual attendance". Besides, it is both portable and versatile without sacrificing audio and video quality. This virtual attendance is achieved through empowerment of the following aspects:

- Audio: For communication among multiple users, it is imperative to transmit and receive audio without any defects, micro-cuts, return-audio, echo, noise, and so on.

- Video: The high-definition video quality offered by AVIP classrooms Level 1 is hardly achievable by any other equipment. However, high-definition video may not always be necessary for mere interactivity.

- Content: Besides video and audio, one fundamental requirement of the AVIP tool is interactive content sharing. That content can be images, office documents, notes on a blank page or on a document, desktop sharing, and so on.

For equipping classrooms AVIP $1+$, multi-platform and technology policy are adopted at the UNED. Thus, the choice of equipment is restricted to looking for the best software to complement the tools 2.0, prioritizing quality, interoperability, ease of use, and 
affordability. The basic equipment that makes up the design of these new classes is as follows:

- computer,

- projector,

- webcam,

- peripheral room audio with echo cancellation,

- interactive whiteboard.

The following figure illustrates the interoperability of classroom resources in a real situation, using the tool Audio-Visual IP (AVIP) in telematic tutoring.

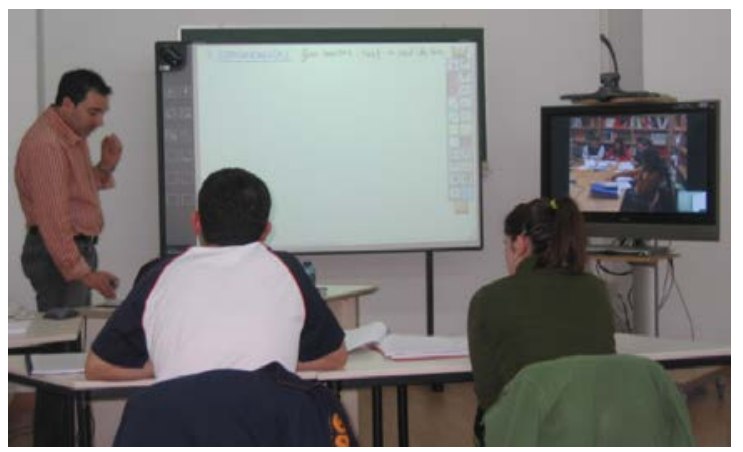

Figure 2. AVIP 1+.

Connectivity between videoconferencing equipment can be established in two ways, depending on the number of participants.

Point to point: between two distant locations.
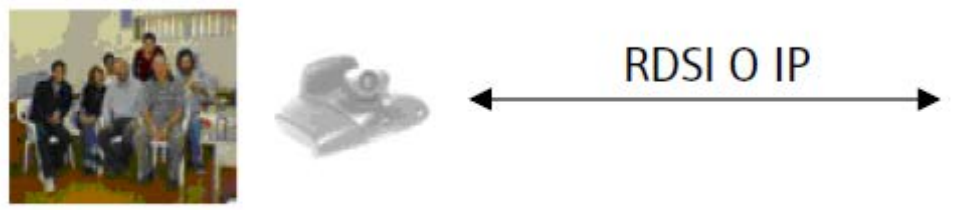

AVIP1

AVIP2

Figure 3. AVIP- Videoconferencing point to point. 
Multipoint: People involved in the videoconferencing are at three or more locations. To conduct a multipoint videoconference, at least one MCU (Multipoint Control Unit) is required, which can be an integrated one or an external one.

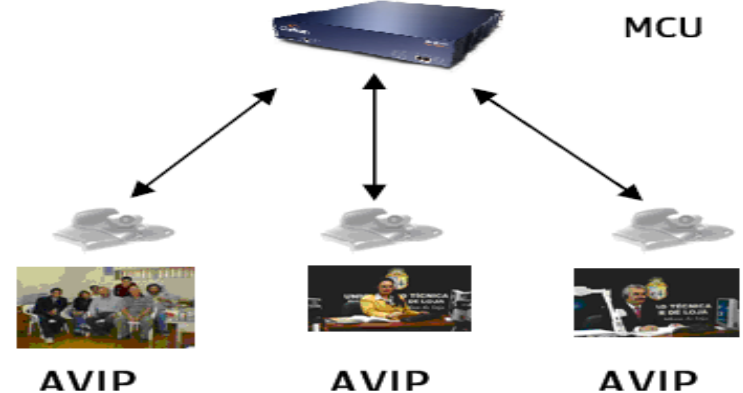

Figure 4. AVIP- Videconferencia multipunto.

The sessions in AVIP Classroom can be recorded in high quality (HD), including signal capture, videoconferencing equipment (H.323), and graphics that come from the PC (presentations, web board), generating a video in FLV format (Flash Video), which can then be played via streaming. Thus, the teaching and learning processes in this university are carried out by a combination of four parameters: face-to-face tutoring, virtual tutoring, blended learning, and distance learning, following the principles of virtual presence. The following figure illustrates the relationship between them.

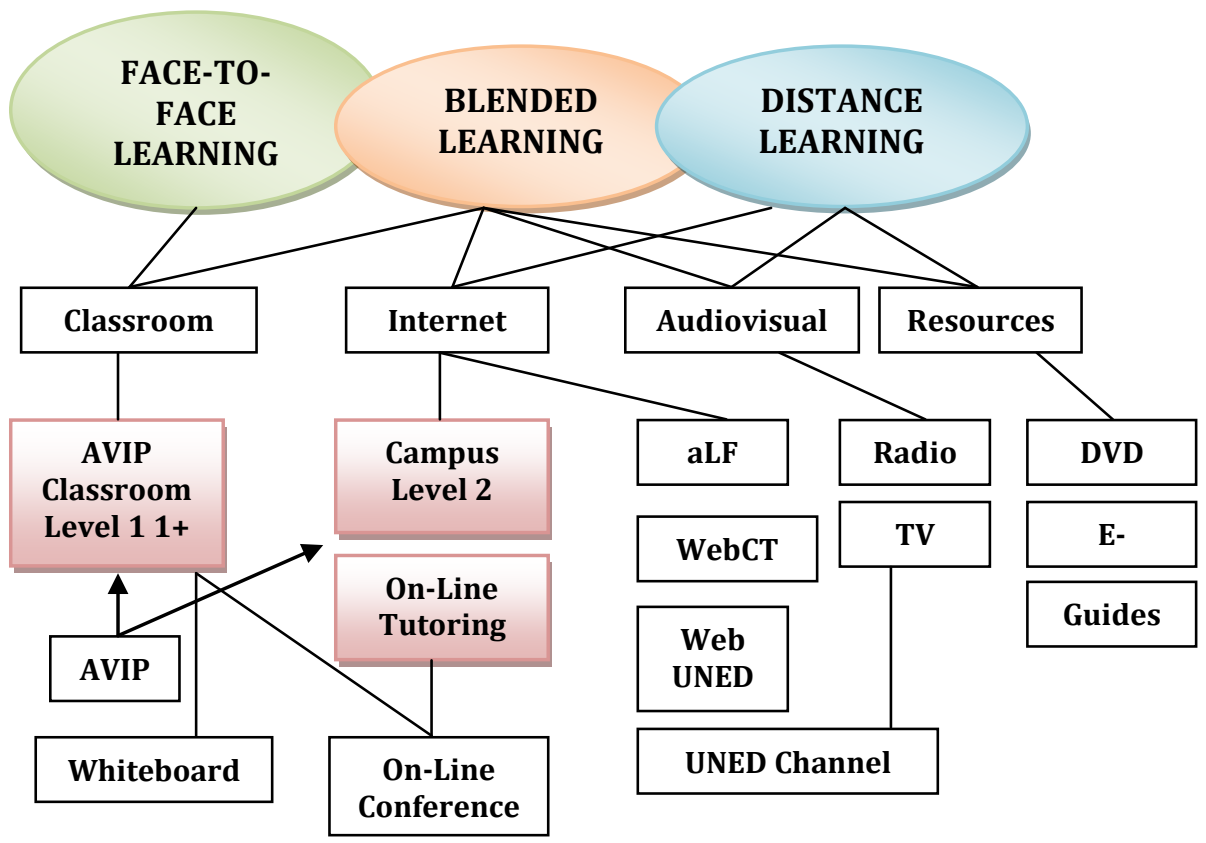

Figure 5. UNED model of distance learning 
UNED has chosen this model in order to meet the demands of teaching within the EHEA and adapt its VLE called aLF with web conferencing functions to fulfill the demands of virtual attendance. All activities, tests, and exams done in AVIP are transferred automatically to aLF in order to assess and orientate the learning progress of the students, and all students' profiles and activities can be seen by each professor at the central site of UNED in Madrid. The AVIP system compares to other systems in the following ways: Adobe Connect, Saba, or Blackboard allows students to create and share content with other students and teachers at the same time the classroom is being developed and automatically recorded on aLF. Students can choose, depending on their location, to attend blended-learning classes at a centralized learning centre near their work or home where they have their tutors (they do not evaluate), internet access, library, tutorials, and additional printed material to prepare their subjects, or being at home, if they have internet access, following the video class and participating on-line. These centers allow all kinds of economies and, especially, low-income students to succeed in their studies. These capabilities convert AVIP in a flexible tool which combines aLF and web conferencing; it enables students to maintain rich and fluid communication with their tutors, lecturers, and peers and permits them to work collaboratively in the preparation of the assignments they have to undertake on these courses. Actually, UNED is connecting the AVIP system to existing social networks (Twitter, Facebook, etc.) and creating Apps to see video lessons in smartphones (available in Google play store). From this application you can play recordings and video, interact with the notes made by the speakers, check the chat, or download the documents used in the session.

\section{Research Questions}

The goal of this study was to gain better insight into the characteristics of audiovisual methods for developing "virtual attendance" in distance learning university studies. The focus, therefore, has been on answering the following three research questions regarding the advantages of the new model of videotutoring over IP:

1. What are the perceptions of tutors and students about the functionality of the new model of videotutoring over IP?

2. What practices and strategies do tutors and students use to develop their lessons through this new model?

3. What challenges and difficulties do tutors and students encounter in this new model? 


\section{Method}

The purpose of this case study was to examine the functionalities, perceptions, and challenges of tutors and students who teach and study with the help of the videotutoring model over IP in the Spanish Open University. The purpose of phenomenological research is not to obtain generalizations, but to describe in detail the breadth and depth of individual experience with the phenomenon and the meaning structures of such experience (Creswell, 2003). The commonality of this particular study was three educational associated centers in different regions of Spain (Madrid, Andalucía, and Castilla-La Mancha). The range and types of institutions, rather than representing a difficulty, symbolize a methodological enrichment that generates greater validity to the findings, providing a general explanation in multiple contexts. Thus, contrasting these different educational centers and testing our hypotheses and conclusions in multiple educational settings, we provide a method to generate substantive theories, with different levels of depth concerning the amount of information collected and the sample of people involved: tutors, administrators, and students. Thus, this study is implemented based on action research methodology. Since it has the characteristics concerning the development of application, the approach employed in the scope of the study requires the implementation of "practice oriented-action research" (Holter \& Schwartz-Barcott, 1993). In this process, survey and questionnaire techniques are used. In the execution of the research, a survey and structured interview form was utilized for data collection.

\section{Data Collection and Analysis}

The case study was carried out during 2010-2011 and we can see the key informants in Table 1.

Table 1

Sample

\begin{tabular}{ccc}
\hline & $\begin{array}{c}\text { University } \\
\text { tutors }\end{array}$ & Students \\
\hline Madrid & 171 & 256 \\
Castilla-La Mancha & 43 & 101 \\
Andalucía & 87 & 220 \\
\hline
\end{tabular}




\section{Procedure}

One questionnaire, which included three sections, was developed.

1. General questions: This section relates to the tutors and students' gender, number of years of experience and university studies, and self-rating of skills in using ICT (Tables $2 \& 3$ ).

2. Perception of use and main characteristics: This section includes 11 items relating to tutors and students' views on the use of the videotutoring model through IP. These items are rated on a Likert scale, ranging from "Very Dissatisfied" to "Very Satisfied" (Tables 4-6).

3. Training, challenges, and difficulties in developing videotutoring for distance education: This section includes 17 items that address the difficulties involved in performing teaching and tutoring, and in studying these activities in the digital context; the items also address the challenges perceived by tutors and students. The items are rated on a four-point scale, ranging from "Not Important" to "Essential" (Tables 7-9).

\section{Analysis}

Analysis involved iterative cycles of examination of the data, identification of key themes, and the drawing of tentative conclusions confirmed (or refined) using a combination of techniques: triangulation, checking for representativeness, respondent validation, investigation of rival explanations, checking/replication of findings, and the examination of outlier cases (Keeves \& Sowden, 1997). This approach was consistent with Sowden and Keeves' general framework (1988) for the analysis of qualitative data as a three-step process: 1) data reduction, 2) display and examination, and 3) conclusion drawing and verifying. This process was applied at three points in the study: first, to the ongoing analysis in the dialogical process for each case; second, at the conclusion of information collection for each case; and third, at the end of all information collection for the study. For the Likert items, $\alpha$-scale construction was carried out by applying principal component analyses and by calculating Cronbach's $\alpha-$ scores. Items that reduced the $\alpha$-score were excluded from the scales. Subsequently, mean scores per scale were calculated. In order to assess the influence of background variables on the tutoring and studying activities, Pearson correlation coefficients were calculated and multiple regression analyses were carried out.

The questionnaire was completed by 301 tutors and 577 students. Males formed the majority (60.13\%) among tutors and females (61.70\%) among students. The experience of tutors was in the range of 1 to 10 years (86\%). Three out of four tutors (85.7\%) rated their computer skills as fair or good and $67.23 \%$ of the students as poor to average. As regards the hours of using computing tools, it was in the range of 1 to 6 hours a week for both tutors and students (72.08\%). In this analysis, 95\% confidence interval, taken, and 
discriminant validity of the survey consists of 28 items by subtracting non-distinctive 4 items was calculated as Cronbach's alpha value of 0.94 . The questionnaire could therefore be considered representative in explaining the students' and tutors' learning satisfaction with the videotutoring model. The recovered questionnaires were analyzed using SPSS version 18.0 software.

Tables 2 and 3 show the results of Levene's test. As can be seen, all results in macro variables were statistically significant. The results of the independent sample t-test showed that both "Teaching experience" ( $p=.462 \leq .05)$ and "Academic year" $(p=.442$ $\leq$.05) reached a level of statistical significance, indicating that there was a significant difference that conditions the development of videotutoring satisfaction between students and tutors. Regarding the two dimensions of skills and hours of using tools 2.0 ( $\mathrm{p}=.753>.05$ and $\mathrm{p}=.680>.05$ ) for social context and online communication, respectively, no significant differences in perceived social context and online communication were indicated for the students and tutors.

Table 2

Dimension 1: Macrovariables (Tutors)

\begin{tabular}{|c|c|c|c|c|c|c|}
\hline \multirow[t]{2}{*}{ Macrovariables } & \multirow[t]{2}{*}{ Items } & \multirow[t]{2}{*}{$\mathrm{F}$} & \multirow[t]{2}{*}{$\%$} & \multicolumn{2}{|c|}{$\begin{array}{c}\text { Levene's test for } \\
\text { equality of variances }\end{array}$} & \multirow[t]{2}{*}{ t-value } \\
\hline & & & & $\mathrm{F}$ & Sig & \\
\hline \multirow{2}{*}{ Gender } & Male & 181 & 60.13 & \multirow{2}{*}{.206} & \multirow{2}{*}{.653} & \multirow{2}{*}{.046} \\
\hline & Female & 120 & 39.87 & & & \\
\hline \multirow{5}{*}{$\begin{array}{l}\text { Teaching experience } \\
\text { (years) }\end{array}$} & $1-5$ & 143 & 47.50 & \multirow{5}{*}{.033} & \multirow{5}{*}{.858} & \multirow{5}{*}{0.71} \\
\hline & $6-10$ & 102 & 33.89 & & & \\
\hline & $11-15$ & 29 & 9.63 & & & \\
\hline & $16-20$ & 24 & 7.97 & & & \\
\hline & +20 & 3 & 0.99 & & & \\
\hline \multirow{4}{*}{$\begin{array}{l}\text { Tutor's skills in the use } \\
\text { of ICT }\end{array}$} & Poor & 56 & 18.60 & \multirow{4}{*}{.026} & \multirow{4}{*}{.871} & \multirow{4}{*}{-.311} \\
\hline & Regular & 87 & 28.90 & & & \\
\hline & Fair & 176 & 58.47 & & & \\
\hline & Good & 82 & 27.24 & & & \\
\hline \multirow{5}{*}{$\begin{array}{l}\text { Hours of training related } \\
\text { to using tools } 2.0 \text { (per } \\
\text { week) }\end{array}$} & None & 78 & 25.91 & \multirow{5}{*}{.391} & \multirow{5}{*}{.553} & \multirow{5}{*}{-.414} \\
\hline & $1-3$ & 100 & 33.22 & & & \\
\hline & $4-6$ & 87 & 28.90 & & & \\
\hline & $7-10$ & 23 & 7.64 & & & \\
\hline & $\begin{array}{l}11 \text { and } \\
\text { more }\end{array}$ & 13 & 4.31 & & & \\
\hline
\end{tabular}


Table 3

Dimension 1: Macrovariables (Students)

\begin{tabular}{|c|c|c|c|c|c|c|}
\hline \multirow[t]{2}{*}{ Macrovariables } & \multirow[t]{2}{*}{ Items } & \multirow[t]{2}{*}{$\mathrm{F}$} & \multirow[t]{2}{*}{$\%$} & \multicolumn{2}{|c|}{$\begin{array}{c}\text { Levene's test for } \\
\text { equality of variances }\end{array}$} & \multirow[t]{2}{*}{ t-value } \\
\hline & & & & $\mathrm{F}$ & Sig & \\
\hline \multirow{2}{*}{ Gender } & Male & 221 & 38.30 & \multirow{2}{*}{.211} & \multirow{2}{*}{.641} & \multirow{2}{*}{.041} \\
\hline & Female & 356 & 61.70 & & & \\
\hline \multirow{4}{*}{ Academic year } & 1 & 287 & 49.74 & \multirow{4}{*}{.031} & \multirow{4}{*}{.851} & \multirow{4}{*}{0.73} \\
\hline & 2 & 151 & 26.16 & & & \\
\hline & 3 & 102 & 17.67 & & & \\
\hline & 4 & 37 & 6.41 & & & \\
\hline \multirow{4}{*}{$\begin{array}{l}\text { Level of computer } \\
\text { knowledge }\end{array}$} & Poor & 99 & 17.15 & \multirow{4}{*}{.021} & \multirow{4}{*}{.862} & \multirow{4}{*}{-302} \\
\hline & Regular & 289 & 50.08 & & & \\
\hline & Fair & 111 & 19.23 & & & \\
\hline & Good & 78 & 13.51 & & & \\
\hline \multirow{5}{*}{$\begin{array}{l}\text { Hours of study using } \\
\text { tools } 2.0 \text { (per week) }\end{array}$} & None & 57 & 9.87 & \multirow{5}{*}{.387} & \multirow{5}{*}{.541} & \multirow{5}{*}{-.403} \\
\hline & $1-3$ & 203 & 35.18 & & & \\
\hline & $4-6$ & 156 & 27.03 & & & \\
\hline & $7-10$ & 54 & 9.35 & & & \\
\hline & $\begin{array}{l}11 \text { and } \\
\text { more }\end{array}$ & 107 & 18.54 & & & \\
\hline
\end{tabular}

\section{Results and Discussion}

\section{Dimension 2: Main Characteristics and Tools of Videotutoring Model over IP}

Table 4 lists the items relating to "Perception of main characteristics of videotutoring over IP". They refer to the main AVIP's characteristics employed in face-to-face, multipoint, and single-point classes, and in virtual contexts. Most tutors and students (n $=220,73 \%$ and $\mathrm{n}=410,71 \%$ ) consider that both multi- and single-point digital resources are quite useful in developing their classes off-line. 
Table 4

Perception of Main Characteristics of Videtotutoring through IP

\begin{tabular}{lccccc}
\hline Items & $\begin{array}{c}\text { Very } \\
\text { dissatisfied } \\
\text { Tutor / } \\
\text { student }\end{array}$ & $\begin{array}{c}\text { Dissatisfied } \\
\text { Tutor } \\
\text { student }\end{array}$ & $\begin{array}{c}\text { Neutral } \\
\text { Tutor / } \\
\text { student }\end{array}$ & $\begin{array}{c}\text { Satisfied } \\
\text { Tutor / } \\
\text { student }\end{array}$ & $\begin{array}{c}\text { Very } \\
\text { satisfied } \\
\text { Tutor / } \\
\text { student }\end{array}$ \\
\hline $\begin{array}{l}\text { a) Videoconferencing } \\
\text { AVIP one point }\end{array}$ & $8 \% / 9 \%$ & $7 \% / 11 \%$ & $12 \% / 11 \%$ & $37 \% / 39 \%$ & $36 \% / 30 \%$ \\
b) Videoconferencing & $9 \% / 11 \%$ & $8 \% / 8 \%$ & $10 \% / 10 \%$ & $35 \% / 41 \%$ & $38 \% / 30 \%$ \\
$\begin{array}{l}\text { AVIP multi point } \\
\text { C) Videoconferencing }\end{array}$ & $5 \% / 4 \%$ & $6 \% / 7 \%$ & $10 \% / 11 \%$ & $41 \% / 43 \%$ & $38 \% / 35 \%$ \\
AVIP off-line &
\end{tabular}

Tutors/ Students: 3 items; four-point Likert scale (1- 5); mean =3.31/ 3.48; standard deviation $=0.37 / 0.36 ; \mathrm{N}=301 / 577$

Table 5 presents details of the main tools 2.0 used in AVIP classrooms. Most tutors consider that video $(\mathrm{n}=238,79 \%)$, chat $(\mathrm{n}=217,72 \%)$, and interactive documents $(\mathrm{n}=$ $238,79 \%$ ) are the most useful resources in AVIP classrooms; whereas, students consider that chat ( $\mathrm{n}=415,72 \%)$ and off-line content $(\mathrm{n}=467,81 \%)$ are the two most valuable digital resources.

Table 5

Assessment of Main Tools of Videtotutoring over IP

\begin{tabular}{lccccc}
\hline \multicolumn{1}{c}{ Items } & $\begin{array}{c}\text { Very dissatisfied } \\
\text { Tutor / student }\end{array}$ & $\begin{array}{c}\text { Dissatisfied } \\
\text { Tutor / } \\
\text { student }\end{array}$ & $\begin{array}{c}\text { Neutral } \\
\text { Tutor / } \\
\text { student }\end{array}$ & $\begin{array}{c}\text { Satisfied } \\
\text { Tutor / } \\
\text { student }\end{array}$ & $\begin{array}{c}\text { Very } \\
\text { satisfied } \\
\text { Tutor / } \\
\text { student }\end{array}$ \\
\hline a) Video & $4 \% / 5 \%$ & $5 \% / 6 \%$ & $11 \% / 10 \%$ & $46 \% / 41 \%$ & $34 \% / 38 \%$ \\
b) Audio & $8 \% / 10 \%$ & $7 \% / 8 \%$ & $11 \% / 13 \%$ & $41 \% / 44 \%$ & $33 \% / 38 \%$ \\
c) Interactive & $15 \% / 14 \%$ & $16 \% / 18 \%$ & $21 \% / 23 \%$ & $30 \% / 31 \%$ & $18 \% / 24 \%$ \\
whiteboard & $5 \% / 4 \%$ & $5 \% / 5 \%$ & $11 \% / 10 \%$ & $47 \% / 49 \%$ & $32 \% / 32 \%$ \\
d) Digital documents & $9 \% / 10 \%$ & $7 \% / 8 \%$ & $12 \% / 18 \%$ & $33 \% / 39 \%$ & $39 \% / 33 \%$ \\
e) Chat & $12 \% / 14 \%$ & $16 \% / 17 \%$ & $21 \% / 20 \%$ & $33 \% / 31 \%$ & $18 \% / 18 \%$ \\
f) Pools & $2 \% / 3 \%$ & $5 \% / 6 \%$ & $8 \% / 9 \%$ & $41 \% / 45 \%$ & $44 \% / 37 \%$ \\
g) Off-line content &
\end{tabular}

Tutors/ Students: 7 items; four-point Likert scale (1-5); mean $=3.30 / 3.46$; standard deviation $=0.35 / 0.35 ; \mathrm{N}=301 / 577$ 
Table 6 considers the assessment of the main interactive models. Both tutors and students consider that the model of tutor in the associated center and students at home ( $\mathrm{n}=238,79 \%$ and $\mathrm{n}=467,81 \%$ ) is the best model.

Table 6

Assessment of Interactive Models

\begin{tabular}{lccccc}
\hline \multicolumn{1}{c}{ Items } & $\begin{array}{c}\text { Very } \\
\text { dissatisfied } \\
\text { Tutor / } \\
\text { student }\end{array}$ & $\begin{array}{c}\text { Dissatisfied } \\
\text { Tutor / } \\
\text { student }\end{array}$ & $\begin{array}{c}\text { Neutral } \\
\text { Tutor / } \\
\text { student }\end{array}$ & $\begin{array}{c}\text { Satisfied } \\
\text { Tutor / } \\
\text { student }\end{array}$ & $\begin{array}{c}\text { Very } \\
\text { satisfied } \\
\text { Tutor / } \\
\text { student }\end{array}$ \\
\hline a) Tutor and students in the & $15 \% / 14 \%$ & $16 \% / 18 \%$ & $21 \% / 23 \%$ & $30 \% / 31 \%$ & $18 \% / 24 \%$ \\
& $\begin{array}{l}\text { same or different } \\
\text { associated center }\end{array}$ & & & & \\
b) Tutor and students at home & $5 \% / 4 \%$ & $5 \% / 5 \%$ & $11 \% / 10 \%$ & $47 \% / 49 \%$ & $32 \% / 32 \%$ \\
c) Off-line videoconferencing & $9 \% / 10 \%$ & $7 \% / 8 \%$ & $12 \% / 18 \%$ & $33 \% / 39 \%$ & $39 \% / 33 \%$ \\
\hline
\end{tabular}

Tutors/ Students: 3 items; four-point Likert scale (1-5); mean =3.29/3.49; standard deviation $=0.33 / 0.34 ; \mathrm{N}=301 / 577$

The results show key aspects of the way by which AVIP classrooms, based on videotutoring, can improve the distance teaching-learning process when students receive the content through virtual attendance. Tutors and students emphasize that the use of AVIP classrooms improves interactivity between students and tutors. They rated the following tools as the best: multipoint videoconferencing mode, chats, forums, and access to recorded material during the tutorials.

\section{Dimension 3: Training, Challenges, and Difficulties in the Development of Videotutoring on Distance Education}

Table 7 shows the importance of tutor training in using videoconferencing and in moderating chats and forums for academic purposes ( $n=485$, 84\% and $n=462,80 \%$ ). Students also perceive the need for training in using chats and forums for academics and for creating collaborative audiovisual materials ( $n=241,80 \%$ and $n=280,93 \%$ ). 
Table 7

Training

\begin{tabular}{lcccc}
\hline \multicolumn{1}{c}{ Items } & $\begin{array}{c}\text { Not } \\
\text { important } \\
\text { Tutor / } \\
\text { student }\end{array}$ & $\begin{array}{c}\text { Somewhat } \\
\text { important } \\
\text { Tutor / } \\
\text { student }\end{array}$ & $\begin{array}{c}\text { Very } \\
\text { important } \\
\text { Tutor / } \\
\text { student }\end{array}$ & $\begin{array}{c}\text { Essential } \\
\text { Tutor / } \\
\text { student }\end{array}$ \\
\hline $\begin{array}{l}\text { a) Specific use of videotutoring } \\
\text { b) Creating/ using audiovisual }\end{array}$ & $4 \% / 2 \%$ & $12 \% / 11 \%$ & $31 \% / 34 \%$ & $53 \% / 53 \%$ \\
$\begin{array}{c}\text { materials } \\
\text { c) Moderating/ using chats and }\end{array}$ & $2 \% / 0 \%$ & $8 \% / 7 \%$ & $41 \% / 38 \%$ & $49 \% / 55 \%$ \\
forums & $8 \% / 4 \%$ & $12 \% / 8 \%$ & $52 \% / 62 \%$ & $28 \% / 26 \%$ \\
d) Knowing security systems. & $15 \% / 16 \%$ & $56 \% / 58 \%$ & $19 \% / 18 \%$ & $10 \% / 8 \%$ \\
\hline
\end{tabular}

Tutors/Students: 4 items; four-point Likert scale (1-4); mean $=3.33 / 3.47$; standard deviation $=0.36 / 0.36 ; \mathrm{N}=301 / 577$

Table 8 lists the major difficulties of tutors in using AVIP classrooms: using interactive whiteboard systems and network security ( $n=217,72 \%$ and $n=256,85 \%)$. To students, the main difficulty is in creating and using digital material of the interactive whiteboard ( $\mathrm{n}=421,73 \%$ ).

Table 8

Difficulties

\begin{tabular}{lcccc}
\hline \multicolumn{1}{c}{ Items } & $\begin{array}{c}\text { Slight } \\
\text { Tutor / } \\
\text { student }\end{array}$ & $\begin{array}{c}\text { Low } \\
\text { Tutor / } \\
\text { student }\end{array}$ & $\begin{array}{c}\text { Normal } \\
\text { Tutor / } \\
\text { student }\end{array}$ & $\begin{array}{c}\text { High } \\
\text { Tutor / } \\
\text { student }\end{array}$ \\
\hline a) Use of 2.0 tools & $19 \% / 23 \%$ & $22 \% / 20 \%$ & $18 \% / 22 \%$ & $41 \% / 35 \%$ \\
b) Use of video & $28 \% / 31 \%$ & $19 \% / 23 \%$ & $15 \% / 21 \%$ & $38 \% / 45 \%$ \\
c) Use of audio & $26 \% / 25 \%$ & $27 \% / 28 \%$ & $21 \% / 22 \%$ & $26 \% / 25 \%$ \\
d) Use of interactive & $15 \% / 9 \%$ & $14 \% / 18 \%$ & $19 \% / 13 \%$ & $52 \% / 60 \%$ \\
$\quad$ whiteboard & $7 \% / 8 \%$ & $8 \% / 11 \%$ & $11 \% / 10 \%$ & $74 \% / 71 \%$ \\
e) Security systems & $40 \% / 38 \%$ & $39 \% / 29 \%$ & $12 \% / 31 \%$ & $9 \% / 2 \%$ \\
f) Chat & $26 \% / 15 \%$ & $17 \% / 18 \%$ & $31 \% / 42 \%$ & $26 \% / 25 \%$ \\
g) Recording classes & &
\end{tabular}

Tutors/Students: 7 items; four-point Likert scale (1-4); mean =3.33/3.34; standard deviation $=0.31 / 0.36 ; \mathrm{N}=301 / 577$.

Table 9 shows the major challenges faced by tutors and students in developing teachinglearning processes in a virtual context through implementation of AVIP classrooms. From Table 9 one can see that the main challenges faced by the tutors are developing 
electronic evaluation of students and using electronic portfolios for tracking their activities ( $n=253,84 \%$ and $n=271,90 \%$ ). Students consider it a challenge to develop social networks and blogs in ways that would help them in dealing with their studies in a more cooperative and collaborative way ( $n=508,88 \%$ ).

Table 9

Challenges

\begin{tabular}{lcccc}
\hline \multicolumn{1}{c}{ Items } & $\begin{array}{c}\text { Not } \\
\text { important } \\
\text { Tutor } \\
\text { student }\end{array}$ & $\begin{array}{c}\text { Somewhat } \\
\text { important } \\
\text { Tutor / student }\end{array}$ & $\begin{array}{c}\text { Very } \\
\text { important } \\
\text { Tutor / } \\
\text { student }\end{array}$ & $\begin{array}{c}\text { Essential } \\
\text { Tutor / } \\
\text { student }\end{array}$ \\
\hline a) E-evaluation & $4 \% / 2 \%$ & $12 \% / 11 \%$ & $31 \% / 34 \%$ & $53 \% / 53 \%$ \\
b) E-portfolio & $2 \% / 0 \%$ & $8 \% / 7 \%$ & $41 \% / 38 \%$ & $49 \% / 55 \%$ \\
c) Develop social networking & $8 \% / 4 \%$ & $12 \% / 8 \%$ & $52 \% / 62 \%$ & $28 \% / 26 \%$ \\
d) Blogs & $15 \% / 16 \%$ & $56 \% / 58 \%$ & $19 \% / 18 \%$ & $10 \% / 8 \%$ \\
e) Wikis & $4 \% / 2 \%$ & $12 \% / 11 \%$ & $31 \% / 34 \%$ & $53 \% / 53 \%$ \\
f) Electronic data bases & $2 \% / 0 \%$ & $8 \% / 7 \%$ & $41 \% / 38 \%$ & $49 \% / 55 \%$ \\
\hline (Google docs or similar) & & &
\end{tabular}

Tutors/Students: 6 items; four-point Likert scale (1-4); mean =3.30/3.41; standard deviation $=0.31 / 0.33 ; \mathrm{N}=301 / 577$

The results show key aspects of the ways by which tutors and students perceive their training needs, difficulties, and challenges to improve the teaching and learning processes mediated by ICT in AVIP classrooms. The focus of training is on effective use of the interactive whiteboard and applying the knowledge of security protocols in preparing the content for transmission over the Internet. The main difficulties are in using video (production, creation, and video sharing) and network security programs.

\section{Variables that Influence the Development of Videotutoring over IP}

Multiple regression analyses were carried out to assess the influence of background variables of tutors and students (see Tables 10 \& 11) on developing audiovisual over IP. 
Table 10

Variables that Influence the Development of Videotutoring; Results from a Multiple Regression Analysis

\begin{tabular}{lcccc}
\hline & $\mathbf{B}$ & $\mathrm{SE}$ & $\beta$ & $\mathrm{p}$ \\
\hline Intercept & $\mathbf{0 . 7 3 7}$ & 0,343 & & \\
Tutor's gender & $\mathbf{- 0 . 2 5 2}$ & 0.071 & -0.151 & 0.001 \\
Tutor's years of experience & $\mathbf{- 0 . 2 9 7}$ & 0.003 & -0.126 & 0.015 \\
Tutor's age & $\mathbf{- 0 . 2 1 0}$ & 0.041 & -0.103 & 0.013 \\
Tutor's skills in the use of ICT & $\mathbf{0 . 2 3 4}$ & 0.027 & 0.167 & 0.014 \\
Hours of training related to using & $\mathbf{- 0 . 2 0 1}$ & 0.025 & -1001 & 0.001 \\
computing tools & & & & \\
\hline
\end{tabular}

Table 11

Variables that Influence the Development of Videotutoring; Results from a Multiple Regression Analysis.

\begin{tabular}{lcccc}
\hline & $\mathbf{B}$ & $\mathrm{SE}$ & $\beta$ & $\mathrm{p}$ \\
\hline Intercept & $\mathbf{0 . 7 3 7}$ & 0,343 & & \\
Student's gender & $\mathbf{- 0 . 2 5 2}$ & 0.071 & -0.151 & 0.001 \\
Student's years of study & $\mathbf{- 0 . 2 9 7}$ & 0.003 & -0.126 & 0.015 \\
Student's age & $\mathbf{- 0 . 2 1 0}$ & 0.041 & -0.103 & 0.013 \\
Student's skills in the use of ICT & $\mathbf{0 . 2 3 4}$ & 0.027 & 0.167 & 0.014 \\
\hline
\end{tabular}

The results show that tutors who are more confident of their skills in using ICT are more likely to use skill-based ICT applications in their tutoring functions. They consider these applications are better suited to improving the tutoring functions. The age of tutors and their tutoring experience are found to influence their perception of the utility of ICT in AVIP classrooms. Young male students are also more confident about the use of videoconferencing in classes and at home. Students are also more confident about the use of videoconferencing after the first year of studies and if they use ICT resources at home more than four hours per week. There is a direct relationship between perception of students' skills and the use of videoconferencing and digital resources in their studies. These variables accounted for $65.1 \%$ of the variance (Pearson's $r=0.16$; $p<$ $0.01)$.

Young and less experienced tutors are more willing to use ICT in their work, whereas female tutors appear to be less favourable than their male counterparts. These variables accounted for $67.3 \%$ of the variance (Pearson's $r=0.16$; $p<0.01$ ). 
In addition, a significant relationship was found between the use of digital learning environment and the hours of in-service and at home training in ICT (Pearson's $\mathrm{r}=$ $0.40 ; \mathrm{p}<0.001$ ). To ensure effective functioning of tutors in virtual environments, a substantial shift is needed from the highly theoretical component of the subjects towards more dynamic tutoring techniques involving testing of the proceedings and online activities. The new e-tutoring requires continuous monitoring of the virtual processes in the following dimensions: didactics, network security, evaluation, development of skills, and new ways of creating content by using 2.0 tools.

\section{Conclusions}

The implementation of the new design of AVIP classroom at UNED, based on interactive videoconferencing, has led to its widespread use across the country as a useful teaching tool. These classes offer tutoring services with a high level of interactivity in video, audio, and content. They are specifically designed for the needs of collaborative online tutoring within the framework of the EHEA. In March 2009, UNED launched a total of 71 new classrooms of this type, which have now increased to approximately 270 , spread over the entire country.

The new technological tools that support "virtual attendance", based on the principles of ubiquity and virtual reality, are poised to improve distance learning for greater interactivity. These methodologies are significantly improved by the new layout of AVIP classrooms, based on videoconferencing services that contributed to their widespread use as a teaching tool all over the country. AVIP classroom is based on a cross-platform and open standards that ensure interoperability by combining different tools (aLF educational platform, digital repositories, etc.), which lend support to the pillars indicated below through the virtual private network, "Network-UNED":

- training methodology, based on "blended learning", augmented to virtual attendance;

- information based on the use of the tools and techniques of Business Intelligence;

- communication-based groupware concept, which encourages collaborative team work.

The research analyzed the tutors and students' perception of the utility of this technology and of the challenges and difficulties they encounter. The analysis shows a high value for both sectors in improving the mentoring process of distance learning. This system has recorded so far more than 13,000 videos for the benefit of the educational community, and trained over 5,500 people in AVIP. These videos, which are kept in the repository Campus UNED, have already attracted more than one million 
visits. This data, along with the General Rating Tool AVIP by users, may indicate how favorably the beneficiaries are disposed to accept this project. The groups' productivity and the level of teaching activities realization are very satisfactory: most students and teachers $(\geq 90 \%$ ) considered them to be very dynamic. This system encourages collaborative work and motivation of learners, and their competencies with data processing and 2.0 tools of the Internet. The system architecture proposed in this paper will provide useful references for practitioners in developing cooperative learning systems.

\section{Limitations, Recommendations, and Future Research}

There are also limitations to this study. Participants in the study are college students and tutors; hence, results of this study cannot be extended to other situations. Therefore, two recommendations are suggested based on the experiences of this research. First, cooperative learning systems should contain better interaction mechanisms to support communication activities among tutors and students in the cooperative learning process. Second, teachers and tutors should be actively involved in online activities with students to stimulate high levels of student interaction. Therefore, this study concludes that establishing a videotutoring comprehensive cooperative learning system and better interaction mechanisms will ensure higher levels of learning performance in the cooperative learning process on distance learning. Finally, a future research direction is suggested: It would be desirable for other researchers in distance universities around the world to establish comparative studies of videoconferencing systems implemented on their campuses. 


\section{References}

Arzuaga, E., \& Kaeli, D. R. (2010, J anuary). Quantifying load imbalance on virtualized enterprise servers. In Proceedings of the First J oint WOSP/ SIPEW international Conference on Performance Engineering (pp. 235-242). San J ose, California, USA. WOSP/ SIPEW '10. ACM, New York, NY.

Bersin \&Associates. (2003). Blended learning: What works?: An industry study of the strategy, implementation, and impact of blended learning. Oakland, CA: Bersin \&Associates.

Biocca, F., Harms, C., \& Burgoon, J . (2003). Toward a more robust theory and measure of social presence: Review and suggested criteria. Presence: Teleoperators and Virtual Environments, 12(5), 456-480.

Brindley, J . E., Walti, C., \& Blaschke, L. M. (2009). Creating effective collaborative learning groups in an online environment. International Review of Research in Open and Distance Learning, 10(3), 1-18.

Caspi, A., \& Blau, I. (2008). Social presence in online discussion groups: Testing three conceptions and their relations to perceived learning. Social Psychology of Education, 11(3), 323-346.

Chou, S.-W., \& Min, H.-T. (2009). The impact of media on collaborative learning in virtual settings: The perspective of social construction. Computer \&Education, 52(2), 417-431.

Chickerur, S., \& Kumar, M. A. (2011). Project based learning in higher education with ICT: Designing and tutoring digital design course at MSRIT, Bangalore. In T.-H. Kim et al. (Eds.), Software engineering, business continuity, and education. Communications in computer and information science (Vol.257, pp. 590-597). Berlin, Heidelberg: Springer.

Conole, G. (2010). Facilitating new forms of discourse for learning and teaching: Harnessing the power of Web 2.0 practices. Open Learning, 25(2), 141-151.

Creswell, J . W. (2003). Research design: Qualitative, quantitative, and mixed methods approach. Thousand Oaks, CA: Sage.

Dennen, V., Darabi, A., \& Smith, L. (2007). Instructor-learner interaction in online courses: The relative perceived importance of particular instructor actions on performance and satisfaction. Distance Education, 28(1), 65-79.

Driscoll, M. (2002). Blended learning: Let's get beyond the hype. elearning, 54. 
Ferdig, R. (2007). Editorial: Examining social software in teacher education. J ournal of Technology and Teacher Education, 15(1), 5-10.

Fombona, J . (2008). Lectura de imagenes y contenidos. Madrid: CEP.

Garrison, D. R., \& Kanuka, H. (2004). Blended learning: Uncovering its transformative potential in higher education. The Internet and Higher Education, 7(2), 95-105.

Garrison, D. R. (1997). Computer conferencing and distance education: Cognitive and social presence issues. In The New Learning Environment: A Global Perspective. Proceedings of the International Conference on Data Engineering World Conference. Pennsylvania State University, University Park.

Gaspar, A., Langevin, S., Armitage, W., Sekar, R., \&Daniels, T. (2008). The role of virtualization in computing education. SIGCSE Bull, 40(1), 131-132.

Gunawardena, C. N., \&Zittle, F. J . (1997). Social presence as a predictor of satisfaction within a computer-mediated conferencing environment. The American J ournal of Distance Education, 1(3), 8-26.

Harms, C., Niederhauser, D., Davis, N., Roblyer, M., \&Gilbert, S. (2006). Educating educators for virtual schooling: Communicating roles and responsibilities. Electronic J ournal of Communication, 16(1/2), 17-24.

Heeter, C. (2003). Reflections on real presence by a virtual person. Teleoperators and Virtual Environments, 12(4), 335-345.

Holter, I. M., \& Schwartz, B. D. (1993). Action research: What is it? How it has been used and how can it be used in nursing? J . of Adv. Nursing, 128, 298-304.

Hurtado, C., \& Guerrero, L. A. (2011). Enhancement of collaborative learning activities using portable devices in the classroom. J ournal of Universal Computer Science, 17(2), 332-347.

Keeves, J.P., \& Sowden, S. (1997). Analysis of descriptive data. In J . Keeves (Ed.), Educational research methodology and measurement: An international handbook (2nd ed., pp. 296- 306). Oxford: Pergamon Press.

Köse, U. (2010). A blended learning model supported with Web 2.0 technologies. Procedia Social and Behavioral Sciences, 2(2), 2794-2802.

Krause, K. (2007). Beyond classroom walls: Students' out-of-class activities and implications for teaching and learning. Nagoya J ournal of Higher Education, 7, 301-318. 
Kumar, N., \& Benbasat, I. (2002). Para-social presence and communication capabilities of a web site. eService J ournal, 1(3), 5-24.

LaPointe, L., \& Reisetter, M. (2008). Belonging online: Students' perceptions of the value and efficacy of an online learning community. International J ournal on E-Learning, 7(4), 641-665.

Lee, M. J . W., \& McLoughlin, C. (2010). Beyond distance and time constraints: Applying social networking tools and Web 2.0 approaches to distance learning. In G. Veletsianos (Ed.), Emerging technologies in distance education (pp. 61-87). Edmonton, AB: Athabasca University Press.

Leh, A. S. (2001). Computer-mediated communication and social presence in a distance learning environment. International J ournal of Educational Telecommunications, 7(2), 109-128.

McLellan, H. (1999). Online education as interactive experience: Some guiding models. Educational Technology, Sept.-Oct., 36-42.

Orey, M. (2002). One year of online blended learning: Lessons learned. Paper presented at the Annual Meeting of the Eastern Educational Research Association, Sarasota, FL.

Read, T., Verdejo, F., \& Barros, B. (2003). Incorporating interoperability into a distributed eLearning system. In Proceedings of ED-MEDIA 2003 (Association for the Advancement of Computing in Education, AACE). Hawaii.

Reay, J . (2001). Blended learning-a fusion for the future. Knowledge Management Review, 4(3), 6.

Rehm, M. (2009). Unified in learning-separated by space: A case study on a global learning programme. Industry and Higher Education, 23(2), 331- 341.

Rooney, J . E. (2003). Blending learning opportunities to enhance educational programming and meetings. Association Managment, 55(5), 26-32.

Rossett, A. (2002). The ASTD e-learning handbook. McGraw-Hill.

Sands, P. (2002). Inside outside, upside downside: Strategies for connecting online and face-to-face instruction in hybrid courses. Teaching with Technology Today, $8(6)$.

Schroeder, A., Minocha, S., \& Schneider, C. (2010). The strengths, weaknesses, opportunities and threats of using social software in higher and further education teaching and learning. J ournal of Computer Assisted Learning, 26(3), 159-174. 
Singh, H., \& Reed, C. (2001). A white paper; Achieving success with blended learning. (ASTD State of the Industry Report). American Society for Training and Development. Centra Software.

Shin, N. (2002). Beyond interaction: The relational construct of transactional presence. Open Learning, 17(2), 121-137.

Tallent-Runnels, M. K., Thomas, J . A., Lan, W. Y., Cooper, S., Ahern, T. C., Shaw, S. M., $\&$ Liu, X. (2006). Teaching courses online: A review of the research. Review of Educational Research, 76(1), 93-135.

$\mathrm{Tu}, \mathrm{C}$. (2002). The measurement of social presence in an online learning environment, International J ournal on E-Learning, 1(2), 34-45.

Tu, C., \& McIsaac, S.M. (2002). The relationship of social presence and interaction in online classes. American J ournal of Distance Education, 16(3), 131-150.

Vázquez, E. (2011). Las nuevas tecnologías en la organización de centros educativos. Madrid: Editorial Académica Española.

Vázquez, E., \&López, E. (2012). Virtual tutoring and counseling in schools. ISRN Education, Vol. 2012.

Vázquez, E., \& Sevillano, M.ㄹ L. (2012). Educadores en red. Elaboración de materiales audiovisuales para la enseñanza. Madrid: Ediciones Académicas-UNED.

Ward, J ., \& LaBranche, G. A. (2003). Blended learning: The convergence of e-learning and meetings. Franchising World, 35(4), 22-23.

Whiteman, J . A. M. (2002). Interpersonal communication in computer mediated learning (White/ opinion paper). (ED 465 997).

Witmer, B. G. \& Singer. M. J . (1998). Measuring presence in virtual environments: A presence questionnaire. Presence : Teleoperators and Virtual Environments, 7(3), 225-240.

Young, J . R. (2002). Hybrid teaching seeks to end the divide between traditional and online instruction. Chronicle of Higher Education, 33.

Young, J ., Birtolo, P., \& McElman, R. (2009). Virtual success: Transforming education through online learning. Learning and Leading with Technology, 36(5), 12-17. 


\section{Athabasca University $\mathbf{Z}$}

(c) 